\title{
Religiosity and spirituality: Conceptualization, measurement and its effect on frugality
}

\author{
Daru Asih $^{\mathrm{a}}$, Made Setini ${ }^{*}$, Basu Swastha Dharmmesta ${ }^{\mathrm{c}}$ and Bernadinus Maria Purwanto ${ }^{\mathrm{c}}$
}

${ }^{a}$ Faculty of Economic and Business, Mercu Buana University, Jakarta, Indonesia

${ }^{b}$ Faculty of Economics and Business, Udayana University, Bali, Indonesia

${ }^{c}$ Faculty of Economic and Business, Gadjah Mada University, Yogyakarta, Indonesia

\section{H R O N I C L E}

Article history:

Received: May 30, 2020

Received in revised format:

May 302020

Accepted: July 6, 2020

Available online:

July 6, 2020

Keywords:

Religiosity

Spirituality

Frugality

\section{A B S T R A C T}

The purpose of this research is to analyze the conceptualization of religiosity and spirituality, as well as to validate the measurement and influence of both constructs on frugality. The importance of this study is to find out whether religious and spiritual individuals have a high of frugality. Frugality as a form of self-control, in the long term can create the welfare of consumers. This is a quantitative research that uses a survey method. The sample, comprising of 539 adults, was taken from the general public. A validation of the construct measurements was done by using an exploratory factor analysis, and a data analysis was carried out by using a multiple regression. The research results reveal that there are differences between religiosity and spirituality. The hypotheses results disclose that there was an insignificant influence of religiosity on frugality, while spirituality had a significant influence on frugality. Testing was also done by classifying the sample based on gender. In the sample of women, it was discovered that religiosity had a significant influence on frugality. Meanwhile, in the sample of men, only spirituality had a significant influence on frugality. It is concluded that the effect of religiosity on frugality was moderated by gender.

\section{Introduction}

For the last few decades, researchers have been interested in conducting in-depth studies on religiosity and spirituality. Debating religious philosophical thinking used to be unheard of or forbidden, but now it is considered acceptable. The newest tendency that needs to be emphasized is the increasing prominence of the feature of religiosity and spirituality, which have resulted in the possibility of separating these two terms (Shinde, 2014). Until now, there is still some debates about these two constructs. These arguments involve conceptual explanations, definition developments, as well as validity and instrument reliability developments. Because there have been limited definitions of religiosity and spirituality, which have historically been blurred, in general, there have surfaced differences between the two concepts (Neff, 2008). King and Crowter (2004) also believe that religiosity and spirituality are two different notions. Religiosity is a group activity with a certain behavior that tends to be social, doctrinal, and characterized according to certain groups/ religions (denominational). Religiosity is related to a person's religious feelings, which are all the inner feelings that are related to God, which tend to be more dogmatic. Meanwhile, spirituality is connected with an individual's inner life, which it seems has positive consequences in one's behavior in an organizational context. There has not been much research into religiosity and spirituality in marketing, especially in terms of customer or consumer behavior, but in its development, until now it has experienced a rather significant increase. Theoretical and conceptual knowledge between marketer's and practitioners regarding measuring the influence of religiosity on consumer behavior and the market is still limited. The operational definitions from the concepts are also still unclear, and 
the problem of measuring religiosity and spirituality tends to be more personal. The conceptualization of religiosity and spirituality reinforce the development of each other. For instance, religious practices encourage spiritual growth. Meanwhile, spirituality often becomes an aspect that stands out from religiosity. Discussing spirituality without this being accompanied by a discussion of religiosity does not have as much meaning (Shinde, 2014). On one side, religion can become a basis to arrange marketing strategies, in order that a product is more interesting for the target consumers, but on another side, religion can also teach frugality. As of now, frugality is still an orientation for the majority of the world's population, whether in advanced countries like the United States and other comparable countries or in developing countries that still has unstable economies. According to Lastovicka et al. (1999), the first time this frugality issue arose was in America about four centuries ago.

Frugality is a form of self-control. All of the major religions support the ethics of suppressing one's materialistic desires and searching for satisfaction through achieving spiritual development. Consumers, in their daily activities, have inner desires to sustain their self-existence and actualize their needs (Lastovicka et al., 1999; Brandt, 1996; Pourmola et al., 2019; Supriyanto et al., 2020). Frugality helps to explain how consumers use goods and services. In addition, frugality is also interesting to study in terms of the measurement issue. Research results show that frugality can become a dependent variable, with its antecedents being personal factors. Several problems examined in this research involve differences between the spirituality construct and the religiosity construct itself, which until now are still being contested. The conceptual definitions of these two things are also still inconclusive. Another insight which will be tested is about the validity of measuring both constructs. There is still very little marketing research which discusses the religiosity and spirituality constructs in-depth, especially related to frugality. Therefore, this research also strives to analyze the influence of religiosity and spirituality on the frugality construct. This frugality construct can be said to be connected with consumer behavior, because various research results found that frugality is an antecedent of purchasing behavior.

\section{Literature Study and Hypotheses Development}

Religion, in the beginning, was conceptualized as a one-dimensional construct, such as one's membership or presence at a place of worship. Guthrie (1980), as quoted by Wilkes, Burnett, and Howell (1986), stated that there are still no theories or definitions about religion that can be generally accepted. This is in line with an opinion by Eister (1974), in that religion is challenged by the social sciences consensus and cannot be defined with one general term, depending on the context. Nevertheless, in its development, religion can become a multidimensional construct. This research discusses the validation of measuring the religiosity, spirituality, and frugality constructs, as well as the influence of the religiosity construct and the spirituality, construct on the frugality construct. Religiosity and spirituality are factors which are related to beliefs. Thus, they can be categorized as personal factors. Therefore, measuring them is also a personal characteristic. Religiosity is a person's religious feeling, which is related to one's religious practices and beliefs. Meanwhile, spirituality places more emphasis on the interconnectedness of individuals and transcendent power (God or a higher power). According to Hicks (2003) and Moberg (2005), discussions about religiosity and spirituality complement each other, as quoted by Shinde (2015). This means that discussing spirituality without religiosity is meaningless. However, certain previous research has stated that religiosity and spirituality are two different things.

\subsection{Contesting Religiosity and Spirituality}

Various definitions about religiosity and spirituality found in the literature are not yet accepted in general. The definitions are from the perspectives of various disciplines and depend on the research settings. Every study proposes its own conceptual definition and measurement. According to Baumsteger and Chenneville (2015), there are inconsistencies in conceptualizing and measuring the constructs, which can weaken the potential value of research into religiosity and spirituality. Johnson et al. (2001) defined the concept of religiosity as a dependence on one's religious teachings which are reflected in one's behavior. Thus, it can be said that religiosity can shape one's attitude and behavior. This was supported by Barnett et al. (1996), who stated that the religiosity concept has three dimensions, which are the cognitive dimension, the affective dimension, and the behavioral dimension. Religiosity coincides with an individual's various feelings, meaning all of one's spiritual feelings that are related to God, which tend to be more dogmatic. Meanwhile, spirituality coincides with individual inner life, which it seems has positive consequences for one's behavior in an organizational context. Marler and Hadaway (2002) researched the interconnectivity between "being religious" and "being spiritual" in Protestants in America. The research results discovered that definition-wise and operationally, religiosity and spirituality are different from each other, and the connection between the two constructs complements each one.

Etymologically, the term "-spiritus-" originates from the Latin language, in which "spiritual" means a spirit or soul behind the shape of an entity which comes alive behind the manifestation of the entity (Lings, 2005). The features of religiosity and spirituality that were prominent in ancient times (before the periods of the Jews-, and Christians, and especially in the periods of the ancient Egyptians, Romans, ancient Greeks, Persians, and the periods before that) were not formulated by any particular religion of that period. The spirituality values that were mostly found in the past, before religion was well-known, had complicated boundaries (intricately bound), and in developing terms or language, spirituality was also referred to as religiosity. In 
other words, spirituality is often equated with religiosity. In its development, at this time there are more studies that differentiate between the religiosity and spirituality constructs.

\subsection{Differences between Religiosity and Spirituality}

Religiosity is different from spirituality. Pargamen (1999) stated that in traditional social science terminology, spirituality is more directed at the functional aspects of religion, or a more intrinsic dimension, while religiosity represents more substantive things or the extrinsic dimension of religion. The differences between religiosity and spirituality are also reinforced by findings from Roof (1993) and Gallup (1999), who supported the assumption that spirituality and religiosity are mutually exclusive (Marler \& Hadaway, 2002). Discussions about religious attitudes and behavior in several recent studies have been directed towards spirituality. Research results by Roof (1989), as found in a study by Marler and Hadaway (2002), discovered that there is confusion between the meaning of religiosity and spirituality. Another study conducted by Zinnbauer et al. (1997) asked participants about their understanding of religiosity and spirituality, by using overall measurements. The research results discovered that 74 percent of the participants stated they were spiritual and religious, 19 percent stated they were spiritual but not religious, four percent stated they were religious but not spiritual, and three percent stated they were not spiritual or religious. The study was carried out on 348 respondents from Christian congregations and religious institutions, the medical and mental health professions, and nursing professions in Pennsylvania and Ohio.

\subsection{Conceptualization and Measurement of Religiosity}

The definition of religiosity is often different between researchers. In social research, a general definition of religiosity is still needed, because until now there is no general agreement to define religiosity's construct. Allport and Ross (1967) defined religiosity as a religious inner experience. According to Cornwall et al. (1986), religiosity is a concept which includes an individual's behavior and the strength of their religious convictions. McDaniel and Burnett (1990) defined religiosity as a commitment to follow the principles of a belief that are determined by God. According to De George (1986), religion is a motivation to be moral and has a source of reference in moral behavior. Magill (1992) mentioned that religiosity coincides with morality and its values are interpreted for ethical behavior. Based on these definitions, according to Barnett et al. (1996), the religiosity concept has three dimensions, which are a cognitive dimension (religious knowledge and beliefs), an effect dimension (religious feelings), and a behavior dimension (going to a place of worship, attending religious activities, among other things). These dimensions are usually used to measure the individual's level of religiosity. The religiosity concept is also defined as one's dependence on religious teachings and reflected in the person's behavior (Johnson et al., 2001). Based on these definitions, Barnett's approach is used to conclude that the number of religious beliefs (affects), worship (behavior), and religious influence in an individual's daily life (effects) reveal an individual's level of religiosity. A different approach was put forward by Johnstone (1975), who identified three approaches in measuring religion. The first approach is organizational, which is related to the dichotomy between members and non-members, major religious families, and denominational affiliations. The second approach is individual, which covers an individual's participation in rituals, the individual's life of daily worship/prayer, and the importance of religion for an individual. The third approach is multidimensional, which includes all the different dimensions that can be used for measuring religiosity, because there are many ways to become religious so that measuring religiosity is rather complicated and complex. This approach is used in an effort to criticize religious measurements that only apply one dimension (Khraim, 2010). Consequently, the dimensionality from this religious construct can be said to be an unsolvable problem, since religion is a human phenomenon that is diverse and complex, which covers fundamental things like behavior, attitude, values, beliefs, feelings, and experiences. Several researchers implicitly believe that religiosity is a unidimensional construct, meaning it is measured with a sole measurement. Meanwhile, a number of other researchers measure religiosity by using multidimensional measurements. As revealed by Bergin (1991) in Khraim (2010), the majority of experts agree that the religious phenomenon is multidimensional.

\subsection{Measuring Religiosity}

In previous studies, an effort was made to measure the level of religiosity, at the individual level, on an individual question scale that generally covered the frequency of ritual attendance. The most common question was "How many times do we attend Sunday worship at church?" This question about church attendance could be replaced with a person's presence at another place of worship, based on one's individual religion. Nevertheless, nowadays when measuring with a sole question like this, it is no longer valid to measure religiosity at the individual level. One significant finding from past research related with this religiosity construct is that there needs to be a multiple-item measurement that can more clearly measure religiosity, due to the inherent complexity of the religiosity construct. A multi-dimensional scale also needs to be developed to study this complicated religiosity construct. Table 1 contains the dimensions from the religiosity construct of previous research. The measurement scale used in this research refers to the Centrality Religiosity Scale (CRS), which was developed by Huber and Huber (2012). CRS was chosen because it has been used in more than 100 studies, in more than 25 countries, and with more than 100,000 participants. The CRS dimensions are considered to be able to represent all religious lives (Huber \& Huber, 2012). This centrality scale refers to the multidimensional religiosity model that was proposed by Glock (1973), who considered religion from a sociological perspective. The five main dimensions that were developed from this sociological perspective also cover religiosity from a psychological perspective. The intellectual and ideological dimension refers to thinking (the 
cognitive aspect), the personal and general practices dimension refers to actions (the behavior aspect), and the experience dimension refers to experiences, emotions, and perceptions (the affective aspect). Thus, these dimensions can be considered as representing religiosity from two perspectives, which are a sociological perspective that reflects social expectations, and a psychological perspective that reflects religious content (Huber \& Huber, 2012).

Table 1

Religiosity Dimensions

\begin{tabular}{|c|c|c|}
\hline Author & Year & Dimension \\
\hline Allport \& Ross & 1967 & $\begin{array}{l}\text { Religiosity intrinsic orientation } \\
\text { Religiosity extrinsic orientation }\end{array}$ \\
\hline Stark \& Glock & 1968 & $\begin{array}{l}\text { Religious conviction } \\
\text { Religious knowledge } \\
\text { Religious practice } \\
\text { Religious experience } \\
\text { Religious consequence }\end{array}$ \\
\hline Wilkes, Burnett, \& Howell & 1986 & $\begin{array}{l}\text { Church attendance } \\
\text { Importance of belief in religious values } \\
\text { Self-preparedness of religiosity }\end{array}$ \\
\hline Strayhorn, Weidman, \& Larson & 1990 & $\begin{array}{l}\text { Self-preparedness of religiosity } \\
\text { Religious awareness } \\
\text { Religious behavior }\end{array}$ \\
\hline McDaniel \& Burnett & 1990 & $\begin{array}{l}\text { Self-preparedness of religiosity, the importance of religion } \\
\text { Church attendance, donation to religious institution }\end{array}$ \\
\hline Delener & 1994 & $\begin{array}{l}\text { Self-preparedness of religiosity } \\
\text { Expression of religious affiliation }\end{array}$ \\
\hline Sood \& Nasu & 1995 & $\begin{array}{l}\text { Self-preparedness of religiosity } \\
\text { Belief in fundamental teachings } \\
\text { Importance of conviction in religious values } \\
\text { Religious behavior }\end{array}$ \\
\hline France \& Kaldor & 2002 & $\begin{array}{l}\text { Belief in God } \\
\text { The frequency of attending church } \\
\text { Frequency of praying }\end{array}$ \\
\hline $\begin{array}{l}\text { Worthington, Wade, Hight, McCullough, Berry, } \\
\text { Ripley, Berry, Schmitt, Bursley, \& O'Connor }\end{array}$ & 2003 & $\begin{array}{l}\text { Religiosity behavior } \\
\text { Motivational/ interpersonal religiosity }\end{array}$ \\
\hline Khraim & 2010 & $\begin{array}{l}\text { Attitude towards Islamic financial services } \\
\text { Attitude towards recent Islamic issues } \\
\text { Attitude towards sensitive products and food consumption } \\
\text { Religious education } \\
\text { Islamic ethics }\end{array}$ \\
\hline Muhamad \& Mizerski & 2010 & $\begin{array}{l}\text { Religious affiliation } \\
\text { Religious knowledge } \\
\text { Religious orientation } \\
\text { Religious consequences } \\
\text { Religious commitment } \\
\end{array}$ \\
\hline
\end{tabular}

Source: Tjahjono (2015)

\subsection{Conceptualization and Measurement of Spirituality}

In more in-depth studies in the social field, spirituality is a human motivation to achieve meaning for oneself and the world (Canda \& Furman, 1999). There is a term called non-religious spiritual tendencies, which depicts an individual who does not use religion as a basis for faith. Spirituality is conveyed as a certain condition related to existential questions such as: "Who am I? Why am I here? What is my life purpose? How can I live properly in the world? "The sociological perspective is oftentimes equated with an existential orientation, because spirituality is represented as depicted by Roof (1993), as providing an expression to one's inner self, a strength that comes from inner and sacred knowledge. As of now, there is no generally agreed upon definition of spirituality. McSherry and Cash (2004) explored several definitions that were quoted in general, especially in a nursing context to reinforce whether this spirituality context can be applied with a universal meaning. It was concluded that there is no universal definition of spirituality. Several recent articles suggest it is better to keep using the various definitions of spirituality and direct them towards the goals, values, and meanings provided, with good and ethical, transcendentalism, self-actualization, and others that tend to be universal.

\subsection{Measuring Spirituality}

Graci (1999) stated that spirituality covers philanthropy, community, compassion, forgiveness, expectations, learning opportunities, meaningfulness, and morality. Besides that, McCormick (1994) explained five themes of spirituality which are considered to be significantly relevant in a global market's context and multicultural workplace's context, which include compassion, right livelihood, selfless service, meditative work, and the problem of pluralism. Shinde (2015) developed an instrument that can measure spirituality at the individual level, which was based on a definition rooted from the perennial perspec- 
tive. The purpose of this study was to define spirituality in a comprehensive and non-ambiguous manner and make the dichotomy by using a universal paradigm from a perennial perspective in the field of philosophy. Beazley (1997) applied spirituality to five primary dimensions, which were two definitive dimensions and three correlated definitions. A study carried out by Baumsteiger and Chenneville (2015) discovered seven evaluation categories in measuring spirituality, which are: 1) Spirituality's power, 2) specific spiritual convictions, 3) spiritual development, 4) the role of spirituality in one's daily life, 5) the influence of spirituality on one's mental health, 6) positive characteristics, attitudes, or behavior which can improve one's mental health, and 7) irrelevant information. The items which measure spirituality's power include the degree an individual's power is oriented towards religiosity or spirituality, and the influence of spiritual power on individual aspects of one's life (in all life aspects or no life aspects). The items which are related with certain spiritual convictions cover those items that are related with one's connection to a higher power, conviction about one's interconnectedness with other factors (people, animals, and nature), and other spiritual beliefs, such as power from outside of humans. The items which measure spiritual development related to insights from other faiths can improve one's spiritual understanding of truth, as well as spiritual conviction's development. The items which measure the role of spirituality in one's daily life include the practice of one's beliefs, such as praying, meditating, or other forms of religious service, the individual's frequency of praying, and spiritual integration in one's daily life. The items which measure the influence of spirituality on one's mental health, positive characteristics, and an attitude or behavior which improves one's good mental health, cover positive feelings, gathering with other people, being involved in spiritual activities, having faith to face life's challenges, as well as avoiding conflict. The items which measure irrelevant information cover enjoyment from listening to music and familiarity with music one has heard before. These research findings by Baumsteiger and Chenneville (2015) reveal that there are several challenges in the scope of evaluating religiosity and spirituality. Researchers must realize that there is ambiguity in the definitions of both constructs and must explicitly describe the operationalization of religiosity and spirituality in their respective studies. As of now, many studies have developed measurements of spirituality. One of the measurements of spirituality that has been frequently used in various studies is the spirituality daily experience measurement scale, which consists of three dimensions, which are the values, or beliefs dimension, the forgiveness dimension, and the positive religious coping dimension. This Daily Spiritual Experiences Scale (DSES) was developed through extensive and qualitative studies so that this scale can be used in various settings, and is not just limited to the health and nursing fields. This scale has been used in more than 70 publications and has proven its usefulness.

\subsection{Conceptualization and Measurement of Frugality}

The Oxford English Dictionary defines frugality as "the quality of being frugal; moderate or sparing expenditures or use of provisions, goods, etc." Synonyms are thrifty, observant, and wise (Goldsmith \& Flynn, 2015). Lastovicka et al. (1999) defined frugality as a single dimension consumer lifestyle that is marked by a level of control and using limited resources, in the form of goods or services, to reach one's long-term goals. The research findings concluded that frugal consumers are those who have the following characteristics: 1) They are disciplined when spending their money; 2) are not impulsive when shopping; 3) prioritize long-term needs; 4) are capable of using and reusing what they own; 5) feel they have more freedom than other people in general; and 6) are not easily influenced by other consumers. High frugality is related with one's choice of goals, ambitions, capabilities, honesty, respect, adherence, responsibility, social compliance, national security, spiritual life, religious obedience, unity with nature, environmental protection, and inner harmony. Todd and Lawson, in Goldsmith and Flynn (2015), stated that low frugality is associated with values that reflect individual tendencies, and high frugality is associated with collective tendencies. This finding by Todd and Lawson supports the finding by Lastovicka et al. (1999), in that the frugality concept is a lifestyle, not a value. Goldsmith et al. (2014) proposed two primary concepts about frugality. First, the two motivating factors that are based on frugal behavior are from external and internal motivations. Individuals who behave frugally, such as limiting their consumption, choosing lower prices, and applying the four R's (reuse, repair, repurpose, and recycle) do so more because of their general economic condition and personal economic situation. These actions are not truly a kind of frugality but are due to constraints from an external situation. Meanwhile, internal frugal behavior more closely resembles an individual's personality or characteristics. People who behave frugally do so because they really want to live unpretentiously. Thus, it can be concluded that frugal behavior is reinforced or weakened by an individual's social and cultural environment, so that frugal behavior is produced from a combination of external economic forces, an adequate social and cultural environment, as well as individual's character and internal values.

Frugality can be considered from various perspectives. According to Lastovicka et al. (1999), the frugality issue first surfaced about four centuries ago. Frugal consumers considered frugality as a form of discipline. The majority of religions rejects acquisition and promotes self-control. The purpose of self-control is to reach spiritual development. The major religions also support the ethics of controlling one's materialistic desires and searching for satisfaction by achieving spiritual development. As a result, it can be concluded that frugality is strongly related to religiosity and spirituality. As a concept that is rooted in culture and religion, frugality can be used as a path to reach happiness and protect one's interconnectivity with the universe. Frugality is also related to transcendental things. A person who seeks freedom and spiritual development will care about the universe and consider frugality as a requirement. It is different from an individual who has a capitalist viewpoint, as frugality will be considered as a negative perception, as anti-consumption. Consumers who are frugal think of frugality as a discipline. This concept of frugality is internally motivated and implies a consumer, who is disciplined in making purchases, and strives 
to receive the best advantages from their money or resources by not wasting them now. Consumers who are externally motivated have few options and must limit their expenditure, but consumers who are internally motivated to live simply will try to live simple lives by having the self-control to be able to save rather than spend. Thus, an individual who is rich with a simple lifestyle will have conservative spending habits and live unpretentiously.

\subsection{Measuring Frugality}

A study to examine frugality was done by Lastovicka et al. (1999). The study's results reveal that measuring frugality can clearly explain the independent variable being tested. In this study, frugality is defined as a consumer's lifestyle, which is a form of single dimension discipline, and it is marked by frugal behavior. The frugality construct was put into effect by using a multiple point scale, consisting of seven items, called the F-Scale (frugality scale). The items in this frugality scale are related to cautiousness in using money and conservative spending. The Cronbach's alpha coefficient was used to test the reliability, and the research results stated that all the items in the frugality scale revealed internal consistency. This frugality scale from Lastovicka et al. (1999) has been frequently used as a reference for continuing research. Therefore, this research will also apply this scale to measure frugality.

\subsection{Influence of Religiosity and Spirituality on Frugality}

Indonesia acknowledges God as stipulated in the first verse of Pancasila, Believe in the Oneness of God. It is also stated in the 1945 constitution and elaborated in the 1999 State Policy No.IV which requires the state to facilitate the growth of religious life in order to achieve harmony. For example, religion is always included as a mandatory subject starting with elementary education and continuing to the university level. The state can act as a mediator when there is religious conflict. Thus, religious life in Indonesia is different from that in other countries. The religiosity in Indonesia is high, however, it is not well implemented in people's daily behavior. There are many cases of crime and unethical behavior. Religion is restricted to rituals and ceremonials. Often religion is used as a tool to gain personal interests. In the context of Indonesia, religiosity does not always affect behavior. It means that the high level of religiosity does not yield good behavior, as required by religions. According to Berry (2005), when research about religiosity started to reduce, there surfaced a spirituality construct in a bigger religiosity context, which covered personal, subjective experiences, and religiosity. Related with the frugality construct, as researched by Lastovicka et al. (1999), the frugality concept can be defined as a consumer's lifestyle characteristics, which are one-dimensional and marked with a level of usage and consumer limitations when using goods and services to achieve long-term goals. Besides producing quality measurements, a study about frugality is empirically beneficial to understand consumers' product usage behavior and consumers' buying behavior. If connected with religiosity, a study by Tjahjono (2015) revealed that religiosity is negatively related to consumers' intentions to purchase expensive products. In religious teachings, frugality reflects using money carefully and having self-control and discipline when making purchasing decisions. This means that a religious person will tend to be more frugal in their buying behavior and will not be easily tempted by exorbitant goods. Based on the results of previous research, the following hypotheses are proposed.

H1: Religiosity has a positive influence on frugality.

$\mathrm{H} 2$ : Spirituality has a positive influence on frugality.

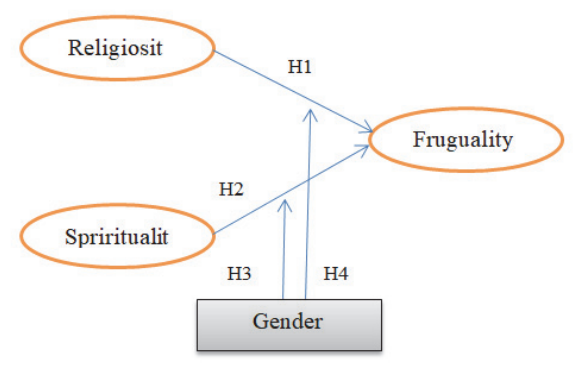

Fig.1. Conceptual framework

Albaity and Rahman (2012) investigated the relationship between religiosity and gender. The results showed that religiosity, when choosing investments is moderated by gender. Male Muslim Malays have a different risk perception from female ones. Bryant (2007) found out that this different spiritual quality is related to religious identity, colleague connectedness, and the level of education. The gender differences in religiosity and spirituality are rarely chosen as the focus of empirical research. Ozorak (2003) stated that relational schemes between men and women are different. In relation to God and religious communities, women focus more on a personal relationship, with the emphasis on God's love, while men tend to live in accordance with God's values when practicing spiritual discipline (Ozorak 1996). Thus, from the findings, further hypotheses can be developed as follows: 
H3: The effect of religiosity on frugality is moderated by gender.

H4: The effect of spirituality on frugality is moderated by gender.

Based on a theoretical study and the results of previous studies and by modifying the conceptual framework of the research obtained in Fig. 1.

\section{The Research Methods and Analysis}

This research used a survey method with quantitative data. A positivistic approach was applied in this study. A positivistic approach uses constructed logic, which is logic about how to conduct research that is very organized and structured in an ideal, formal, and systematic form (Hunt, 1991; Neuman, 2014). This positivistic philosophy is based on empirical testing. This quantitative approach was chosen based on the idea that the constructs that were going to be analyzed in this research had already been tested in previous studies so that the measuring instrument could be adapted for use and retesting in this research. Despite that, since the research setting was different, it was still imperative to undertake validity and reliability testing of the instrument that was going to be used in this survey. This research used a purposive sampling method to obtain respondents with various demographic backgrounds. Various demographic backgrounds will ensure variability of religiosity, spirituality, and frugality necessary to test hypotheses appropriately. This research used a Likert scale, which is a method to measure attitudes with statements of agreement or disagreement towards a particular subject, object, or situation, which in this research was made based on a 5-point measurement, from a scale of 1 (strongly disagree) to a scale of 5 (strongly agree). Thus, the measurements used in this research were included in measuring the interval level, which is the level of measurement that identifies differences between variable attributes, ranking categories, and measurement of the distance between categories, but does not have a real zero value (Neuman, 2014).

\subsection{Operational Definition of Religiosity, Spirituality and Frugality}

In this research, religiosity was also measured with the Centrality Religiosity Scale (CRS) that was developed by Huber and Huber (2012). This study applied religiosity in three dimensions: public practice; private practice; and intellect. Every dimension included three statements. In this research, spirituality was applied by referring to the Spirituality Daily Experience Scale, which consisted of three dimensions: The belief value dimension; the forgiveness dimension; and the positive religious coping dimension. Frugality was utilized in seven statements, which included a feeling of ownership, usage, using goods properly, being frugal in purchasing, being careful in making expenditures, delaying making purchasing decisions, and avoiding spontaneous spending.

\subsection{Testing the Instrument's Validity and Reliability}

The types of validity being tested are convergence and discriminant validity. The instrument's validity was tested by using an exploratory factor analysis, which is by looking at the pattern of indicators' loadings and the size of the factor loadings for every indicator. The measurement is considered valid if the factor loadings exceed 0.4 (Hair et al., 2014). The type of reliability being tested is internal consistency of indicators. The decision-making criteria for a reliable instrument should have a Cronbach's alpha value of more than 0.7 (Nunnally, 1994).

\subsection{Multiple Regression Analysis}

A determination coefficient $\left(\mathrm{R}^{2}\right)$ measured to what extent the model could explain variations in the dependent variable. The determinant coefficient value was between zero and one. Whenever only one independent variable was found, then $R^{2}$ was used. However, whenever there were two or more independent variables, then an adjusted $R^{2}$ was used. The adjusted $R^{2}$ could increase or decrease whenever one independent variable was added to the model. An F statistic test revealed whether all the independent variables in the model had a joint influence toward the dependent variable.

\section{Results and Discussion}

The reliability test results toward the religiosity construct and spirituality construct show that the Cronbach's alpha had a value of 0.854 for religiosity and 0.847 for spirituality, as well as 0.753 for the frugality construct. This means that the three constructs are reliable. This is appropriate with the criteria established by Nunnally (1994), who stated that the Cronbach's alpha value must be above 0.7. A recapitulation of the test results in the gender-based sample is provided in Fig. 2 .

\subsection{The influence of Religiosity on frugality}

H1 is not accepted, from the regression analysis, it was found that there is an insignificant influence of religiosity towards frugality. This is seen from the $t$ statistic value of 0.927 and the probability value of 0.354 , which means it, exceeds 0.05 . Thus, the first hypothesis that religiosity has a positive influence on frugality, is not supported. 


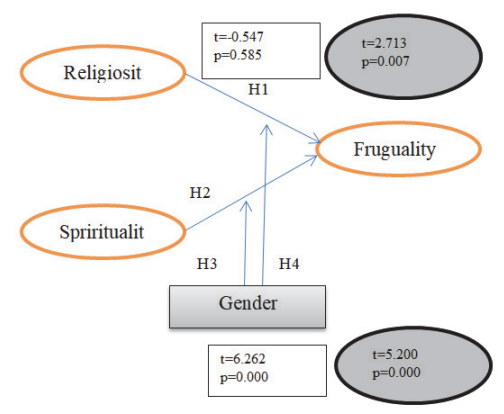

Fig. 2. Test Results of Gender-Based Sample

\subsection{The influence of Spirituality on frugality}

H2 is accepted, for the spirituality construct, the regression analysis results show that spirituality has a significant influence on frugality. This is depicted from the $t$ statistic value of 9.083 and the probability value of 0.00 . Consequently, these research results support the second hypothesis, which is spirituality has a positive influence on frugality. These research results are also in line with previous research findings by Lastovicka et al. (1999), who stated that a spiritual person is no longer oriented towards material satisfaction, so that the individual tends to have frugal behavior and achieves spiritual development.

\subsection{The role of gender engagement in moderating the influence of Religiosity and Spirituality on frugality}

A multiple regression test was also carried out on the sample that was grouped based on gender. From the total of 539 participants taken from the sample, there were 310 females and 229 males. The research results reveal that in the sample of women, the religiosity and spirituality constructs have a significant influence on frugality. In contrast with the sample of women, in the sample of men, only the spirituality construct has a significant influence on frugality.

H3 and $\mathrm{H} 4$ (Gender Women) is accepted, in the sample of women, it was discovered that the religiosity construct and the spirituality construct both had a significant influence on frugality. This is revealed by the $t$ statistic value of 2.713 and the $p$ probability value of 0.007 on the relationship of religiosity with frugality. This implies that frugality for women can be explained by the religiosity construct. Likewise, the influence of spirituality on frugality is also significant, with at statistic value of 0.520 and a p probability value of 0.000 . Therefore, it can be concluded that frugality in women can be explained by the religiosity construct or the spirituality construct.

H3 and $\mathrm{H} 4$ (Gender Man) is not accepted, in the sample of men, the research results convey that there is an insignificant influence of religiosity on frugality, as the $t$ statistic value is -0.547 and the p probability value is 0.585 . Meanwhile, the influence of male spirituality on frugality is found to be significant, with at statistic value of 6.262 and a p probability value of 0.000 . Research findings by Wilkes et al. (1986) revealed that religiosity has a positive relationship with age and gender. It was found that women are more religious than men. This supports a study conducted by Wilkes et al. (1986) related to the influence of religiosity on lifestyle. Thus, frugal behavior by males is not influenced by religiosity but only influenced by spirituality. The descriptive statistical analysis results show that the religiosity level of women is higher than the religiosity level of men, while for spirituality, men are higher than women. The descriptive analysis results are provided in Table 2.

\section{Table 2}

Descriptive Statistical Analysis Results

\begin{tabular}{lllll}
\hline Construct & Average for Women $(\mathbf{N}=\mathbf{3 1 0})$ & Standard Deviation & Average for Men $(\mathbf{N}=\mathbf{2 2 9})$ & Standard Deviation \\
\hline Religiosity & 4.0286 & 0.54559 & 4.0005 & 0.55391 \\
Spirituality & 4.3874 & 0.40049 & 4.4437 & 0.40068 \\
Frugality & 4.2188 & 0.51433 & 4.3130 & 0.47917 \\
\hline
\end{tabular}

Source: Processed data (2020)

The research results reveal that the first hypothesis is not supported. Meanwhile, the research results for the second hypothesis show that it is supported. Thus, it can be concluded that frugality for both men and women can only be explained by spirituality. Meanwhile, religiosity in men or women, based on the research results, cannot explain frugality. Nevertheless, separately, in the sample of women, both hypotheses are supported, in that frugality can be explained by religiosity or spirituality. In contrast, in the sample of men, only spirituality can explain frugality. Therefore, hypothesis $\mathbf{3}$ is supported that the influence of religiosity on frugality is moderated by gender. On the other hand, hypothesis 4 regarding the moderation of gender on the influence of spirituality on frugality is not supported. In addition, mean score of spirituality is higher than that of religiosity for both men sample and women sample. It might explain that both men and women put emphasis on spirutual values than religious ritual and practices. 


\section{Conclusion, Implication, and Suggestion}

The results of exploratory factor analysis have shown that religiosity is different from spirituality. It is in accordance with previous research that showed religiosity is related to extrinsic dimensions while spirituality is related to intrinsic ones (Pargament, 1999). The hypotheses tests have shown that spirituality can explain frugality better than religiosity. Nevertheless, both religiosity and spirituality can explain frugality for women sample. The findings in this research are different from the previous ones in that religiosity generally can affect behavior. The differences are caused by many factors; one of which is that religious life in Indonesia differs from that in other countries. Religious life in Indonesia is supported by the government. It is closely related to the first verse of Pancasila, i.e. "Believe in the Oneness of God." For example, religion is included in the national curriculum. Besides, the government also decided to acknowledge all religious- related holidays. This might result in low variation of religiosity among Indonesian, hence affecting the relationship between religiosity and frugality that is not significant. Some further studies related to religiosity, spirituality, and frugality need to be conducted to verify the results of this study. There are many studies on religiosity and spirituality in the context of Indonesia. However, there is very limited number of studies on religiosity and spirtuality involvingfrugality in the model. It is hoped that these findings can enrich the literature on religiosity and spirituality, especially the ones related to frugality.With regard to practical contribution in promoting frugality, consumer education should address spirituality.

\section{References}

Abdelghani, E. \& Hassanuddeen, A. A. (2012). The Relationship Between Religiosity and Customer Adaption of Islamic Services in Morocco. Oman: Arabian Journal of Business and Management Review, 1(9), 89-94.

Allport, G. W. \& Ross, J. M. (1967). Personal religious orientation and prejudice, Journal of Personality and Social Psychology, 5(4), 432-443.

Applebaum, W. (1951). Studying customer behavior in retail stores. Journal of Marketing, 16(2), 172-178.

Asih, D. (2004). Kecerdasan Emosional-Spiritual (ESQ) dan Kualitas Sumber Daya Manusia: Sebuah Tinjauan Konseptual, Jurnal EKOBIS, 5(1), 87-97.

Baumsteiger, R. \& Chenneville, T. (2015). The challenge to conceptualization and measurement of religiosity and spirituality in mental health research. Journal of Religious Health, 54, 2344-2354.

Berry, D. (2005). Methodological pitfalls in the study of religiosity and spirituality. Western Journal of Nursing Research, 27(5), 628-647.

Brandt, E. (1996). Corporate pioneers explore spirituality. HR Magazine, 41(4), 82-87.

Breczynski, J. \& MacDonald, D. A. (2006). Confirmatory factor analysis of the Allport and Ross religious orientation scale with a Polish sample, The International Journal for the Psychology of Religion, 16(1), 63-76.

Cohen, Z., Holley, L. M., Wengel, S. P., \& Katzman, R. B. (2012). A platform for nursing research on spirituality and religiosity: Definition and measure. Western Journal of Nursing Research, 34(6), 795-817.

Delener, N. (1990). The effects of religious factors on perceived risk in durable goods purchase decisions. Journal of Consumer Marketing, 7(3), 27-38.

Delener, N. (1994). Religious contrasts in consumer decision behaviour patterns: Their dimensions and marketing implications. European Journal of Marketing, 28(5), 36-53.

Eister, A. W. (1974). A sociology of religion by Michael Hill review. The British Journal of Sociology, 25(1),115-116.

Emmons, R. A. (2000). Is spirituality an intelligence? Motivation, cognition, and the psychology of ultimate concern. International Journal for the Psychology of Religion, 10, 3-26.

Essoo, N. \& Dibb, S. (2004). Religious influence on shopping behavior: An exploratory study. Journal of Marketing Management, 20, 683-712.

Francis, L. J. \& Kaldor, P. (2002). The relationship between psychological well-being and Christian faith and practice in an Australian population sample. Journal for the Scientific Study of Religion, 41(1), 179-184.

Frey, B. B. \& Daaleman, T. P. (2005). Measuring a dimension of spirituality for health research: Validity of the spirituality index of well-being, Research on Aging, 27(5), 556-577.

George, L. K., Larson, D. B., Koenig, H. G., \& McCullough, M. E. (2000). Spirituality and health: What we know, what we need to know. Journal of Social and Clinical Psychology, 19(1), 102-116.

Gibbs, P. \& Ilkan, M. (2007). The ethics of marketing in Islamic and Christian communities: Insight global marketing, Equal Opportunities International, 26(7), 678-692.

Goldsmith, R. E., \& Flynn, L. R. (2015). The etiology of frugal spending: A partial replication and extension. Comprehensive Psychology, 4(4),

Hamza, K. (2010). Measuring religiosity in consumer research from an Islamic perspective. Journal of Economic and Administrative Sciences, 26(1), 52-78.

Hicks, D. (2003). Religion and respectful pluralism in the workplace: A constructive framework. Journal of Religious Leadership, 2(1), 23-51.

Hill, P. C. \& Pargament, K. I. (2003). Advances in the conceptualization and measurement of religion and spirituality implications for physical and mental health research. American Psychological Association, Inc. 58(1), 64-74. 
Hill, P. C., Pargament, K. I., Hood, R., McCullough, M., Swyers, J. P., Larson, D. B., \& Zinnbauer, B. J. (2000). Conceptualizing religion and spirituality: Items of commonality, items of departure. Journal for the Theory of Social Behavior, 30(1), 51-77.

Hirschman, E. C. (1982). Religious difference in cognitions regarding novelty seeking and information transfer. Advances in Consumer Research, 10, 228-233.

Huber, S. \& Huber, O. W. (2012). The centrality of religiosity scale. Religions, 3, 710-724.

Johnstone, B., Wallace, R. A., \& Ronald, R. (1976). Religion and society in interaction. Contemporary Sociology: A Journal of Review, 5(4), 537.

Johnstone, B., Yoon, D. P., Franklin, K. L., Schopp, L., \& Hinkebein, J. (2009). Re-conceptualizing the factor structure of the brief multidimensional measure of religiousness /spirituality, Journal of Religion and Health, 48(2), 146-163.

King, J. E. \& Crowter, M. R. (2004). The measurement of religiosity and spirituality. Journal of Organisation Change Management, 17(1), 83-100.

Koenig, H. G. (2012). Religion, spirituality, and health: The research and clinical implications. International Scholarly Research Network, pp. 1-33.

Lastovicka, J. L., Bettencourt, L. A., Hughner, R. S., \& Kuntze, R. J. (1999). The lifestyle of the tight and frugal: Theory and measurement. Journal of Consumer Research, 26(1), 85-98.

Lings, M. (1971). A Sufi Saint of the twentieth century: Shaikh Ahmad al-'Alawi; his Spiritual Heritage and Legacy. Religious Studies, 9(3), 382-383.

Lings, M. (2005). A Return to the Spirit: Questions and Answers. Louisville, KY: Fons Vitae.

Marler, P. L. \& Hadaway, C. K. (2002). "Being Religious" or "Being Spiritual” in America: A Zero-Sum Proposition?

McCormic, D. W. (1994). Spirituality and management. Journal of Managerial Psychology, 9(6), 5-8

McDaniel, S. W. \& Burnet, J. J. (1990). Consumer religiosity and retail store evaluative criteria. Journal of the Academy of Marketing Science, 18(2), 101-112.

Miller, W. \& Thoresen, C. E. (2003). Spirituality, religion, and health: An emerging research field. American Psychological Association, Inc., 58(1), 24-35.

Moberg, D. O. (2005). Research in Spirituality, Religion, and Aging, Journal of Gerontological Social Work, 45(1-2), 11-40.

Muhamad, N. \& Mizerski, D. (2010). The constructs mediating religions' influence on buyers and consumers. Journal of Islamic Marketing, 1(2), 124-135.

Neff, A. J. (2008). A new multidimensional measure of spirituality and religiosity for use in diverse substance abuse treatment population. Journal for the Scientific Study of Religion, 47(3), 393-409.

Neuman, W. L. (2014). Social Research Methods: Qualitative and Quantitative Approach, $7^{\text {th }}$ Ed., Harlow: Pearson Education Ltd.

Pourmola, M., Bagheri, M., Alinezhad, P., \& Nejad, P. (2019). Investigating the impact of organizational spirituality on human resources productivity in manufacturing organizations. Management Science Letters, 9(1), 121-132.

Rahman, S. (2012). Young consumer's perception on foreign made fast moving consumer goods: The role on religiosity, spirituality, and animosity. International Journal of Business and Management Science, 5(2), 103-118.

Shinde, U. S. (2014). Towards a Universal Definition and Measure of Spirituality in the Workplace, A Dissertation, Department of Business Administration in the Graduate School, Southern Illinois University Carbondale. (Unpublished)

Stark, R. \& Glock, C. Y. (1968). Will ethics be the death of Christianity? Society, 5(7), 7-14.

Strayhorn, J. M., Weidman, C. S., \& Larson, D. (1990). A measure of religiousness and its relation to parent, child mental health variables. Journal of Community Psychology, 18, 34-44.

Sood, J. \& Nasu, Y. (1995). Religiosity and nationality: An exploratory study and their effect on consumer behavior in Japan and United States. Journal of Business Research, 34, 1-9.

Supriyanto, A., Ekowati, V., \& Maghfuroh, U. (2020). Do organizational citizenship behavior and work satisfaction mediate the relationship between spiritual leadership and employee performance?. Management Science Letters, 10(5), 1107-1114.

Tjahjono, G. (2015). Religiosity and the Intention to Buy Luxury Goods among Young Indonesian Muslims in Jakarta. Unpublished Ph.D. thesis of Marketing, Sydney, Western Sydney University.

Wilkes, R.E., John, J. B. \& Roy, D. H. (1986). On the meaning and measurement of religiosity in consumer research. Journal of Academy of Marketing Science, 14(1), 47-56.

Wood, R. \& Bandura, A. (1989). Social cognitive theory of organizational management. Academy of Management Review, 14(3), 361-384.

Worthington, E. L. Jr., Wade, N. G., Hight, T. L., McCullough, M. E., Berry, J. T., \& Ripley, J. S. (2003). The religious commitment inventory-10: Development, refinement, and validation of a brief scale for research and counseling. Journal of Counseling Psychology, 50(1), 84-96.

Zohar, D. \& Marshall, I. (2000). SQ: Spiritual Intelligence - The Ultimate Intelligence. New York, NY: Bloomsbury Publishing.

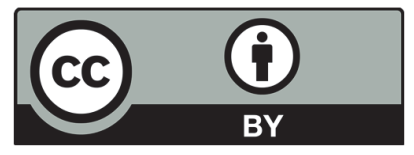

(C) 2020 by the authors; licensee Growing Science, Canada. This is an open access article distributed under the terms and conditions of the Creative Commons Attribution (CC-BY) license (http://creativecommons.org/licenses/by/4.0/). 